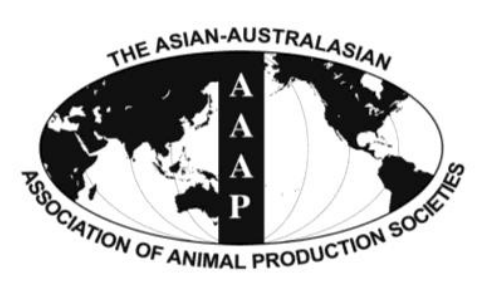

\title{
Effect of Different Tumbling Marination Treatments on the Quality Characteristics of Prepared Pork Chops
}

\author{
Tian Gao ${ }^{1,2}$, Jiaolong $\mathrm{Li}^{1,2}$, Lin Zhang ${ }^{1,2}$, Yun Jiang ${ }^{3}$, Ruixue $\mathrm{Ma}^{1,2}$, Lei Song ${ }^{1,2}$, \\ Feng Gao ${ }^{1,2, *}$, and Guanghong Zhou ${ }^{1,2}$ \\ ${ }^{1}$ Key Laboratory of Animal Origin Food Production and Safety Guarantee, College of Animal Science and Technology, \\ Nanjing Agricultural University, Nanjing 210095, China
}

\begin{abstract}
The effect of different tumbling marination treatments (control group, CG; conventional static marination, SM; vacuum continuous tumbling marination, CT; vacuum intermittent tumbling marination, IT) on the quality characteristics of prepared pork chops was investigated under simulated commercial conditions. The CT treatment increased $(\mathrm{p}<0.05)$ the $\mathrm{pH}$ value, $\mathrm{b}^{*}$ value, product yield, tenderness, overall flavor, sensory juiciness and overall acceptability in comparison to other treatments for prepared boneless pork chops. The CT treatment decreased $(\mathrm{p}<0.05)$ cooking loss, shear force value, hardness, gumminess and chewiness compared with other treatments. In addition, CT treatment effectively improved springiness and sensory color more than other treatments. However, IT treatment achieved the numerically highest $(\mathrm{p}<0.05) \mathrm{L}^{*}$ and $\mathrm{a}^{*}$ values. These results suggested that CT treatment obtained the best quality characteristics of prepared pork chops and should be adopted as the optimal commercial processing method for this prepared boneless pork chops. (Key Words: Tumbling, Continuous, Intermittent, Quality Characteristic, Prepared Pork Chop)
\end{abstract}

\section{INTRODUCTION}

Considering the rapidly increasing demand for meat products suitable for fast food consumption, it would be beneficial to develop simple, easy to prepare, low cost further-processed meat products having improved nutritive values thus providing health benefits for consumers (Gurikar et al., 2014). One value-added meat product is a prepared boneless pork chop cut from pork loins with approximately the same weight and size $(100 \mathrm{~g}$ and 10 $\mathrm{cm} \times 5 \mathrm{~cm} \times 2 \mathrm{~cm}$ ) and then marinated or further-cooked. Such a size is suitable for the marination process and an optimal portion size for eating.

Commercial marinade solutions usually contain a

\footnotetext{
* Corresponding Author: Feng Gao. Tel: +86-25-84399007, Fax: +86-25-84395314, E-mail: gaofeng0629@sina.com

2 Synergetic Innovation Center of Food Safety and Nutrition, Nanjing Agricultural University, Nanjing 210095, China.

${ }^{3}$ Ginling College, Nanjing Normal University, Nanjing 210097, China.

Submitted Jul. 10, 2014; Revised Aug. 25, 2014; Accepted Sept. 16, 2014
}

complex solution of water, salts, polyphosphate, flavorings and other ingredients and are applied to the meat by soaking, blending, tumbling or injection. It is well known that marination is a popular technique used to tenderize and improve the quality characteristics of meat products. Various new techniques have been introduced to accelerate marinade transport throughout the meat. As a kind of physical-mechanical treatment, tumbling is well recognized and accepted (Pietrasik and Shand, 2003). The combination of marination and tumbling provides a useful means of loosening the muscle structures, disrupting muscle cells and destroying the connection between the myofibers and the connective tissue. Also, it promotes the degradation of sarcomere I-filaments and Z-lines, thus facilitating the uniform penetration of the marinade into meat by extracting salt soluble proteins (SSP) (Cassidy et al., 1978; Alvarado and McKee, 2007), and consequently improving the physical characteristics and sensory qualities of prepared pork chops (Plimpton et al., 1991; Yusop et al., 2012).

Tumbling of meat is usually performed using a vacuum tumbler, which promotes marinade solution penetration and

Copyright $@ 2015$ by Asian-Australasian Journal of Animal Sciences This is an open-access article distributed under the terms of the Creative Commons Attribution Non-Commercial License (http://creativecommons.org/licenses/by-nc/3.0/) which permits unrestricted non-commercial use, distribution, and reproduction in any medium, provided the original work is properly cited. 
improves color stability of meat. Tumbling treatments are either continuous or intermittent. Intermittent tumbling is used to obtain a balance between optimal tumbling time and marinade migration time (Hayes et al., 2007), whereas continuous tumbling can effectively avoid intrinsically elastic shrink of tumbled meat samples that occurs in the "rest period" of the intermittent tumbling process. Even though several studies have indicated the advantages of intermittent tumbling (Ockerman and Organisciak, 1978; Plimpton et al., 1991), Gillett et al. (1982) and Hayes et al. (2007) have recommended the use of continuous tumbling.

The objective of this work was, therefore, to determine which method was most suitable for prepared boneless pork chops. We investigated three industrial processes, the conventional static marination method, the vacuum continuous tumbling marination method and the vacuum intermittent tumbling marination method for their effects on the quality characteristics of prepared pork chops in order to determine the process most beneficial for the industry. These were compared with a non-tumbled and un-marinated control.

\section{MATERIALS AND METHODS}

\section{Meat samples and treatments}

For the present study, three fresh whole pork loins (Longissimus dorsi) were obtained randomly from a local slaughterhouse at $48 \mathrm{~h}$ post-mortem. The average weight of slaughtered crossbred barrow pigs [(YorkshirexLandrace) $\times$ Duroc] was approximately $95 \mathrm{~kg}$. The pork loins were chosen as it could be considered as a relatively homogenous muscle with the normal $\mathrm{pH}$ value 5.6 \pm 0.1 . After removal of all external fat, fascia and separable connective tissue, the pork loins were packed in low density polyethylene bags and stored at $2{ }^{\circ} \mathrm{C}$ for subsequent experiments. For testing, one randomly selected pork loin was cut into a total of 16 chop samples of approximately the same weight and size (100 $\mathrm{g}$ and $10 \mathrm{~cm} \times 5 \mathrm{~cm} \times 2 \mathrm{~cm}$ ), and then the chop samples were randomly divided into the following four treatments (4 chop samples per treatment) for the experiments, to give balance to the design. The following four treatments were applied:

i) Control group, $\mathrm{CG}$ (fresh pork chops, no tumbling or marination, temperature at $2^{\circ} \mathrm{C}$ );

ii) Conventional static marination, $\mathrm{SM}(8 \mathrm{~h}$, no vacuum or tumbling, temperature at $2^{\circ} \mathrm{C}$ );

iii) Vacuum continuous tumbling marination, CT $(8 \mathrm{~h}$, 11 revolutions per minute, vacuum at $90 \%$, temperature at $\left.2{ }^{\circ} \mathrm{C}\right)$;

iv) Vacuum intermittent tumbling marination, IT (12 h, $20 \mathrm{~min}$ on and $10 \mathrm{~min}$ off with the actual tumbling time equal to $8 \mathrm{~h}, 11$ revolutions per minute, vacuum at $90 \%$, temperature at $2^{\circ} \mathrm{C}$ ).

The composition of the marinade solution was optimized in preliminary investigations and was designed to give the following concentration of ingredients, percentage by raw meat weight: sodium chloride $(\mathrm{NaCl}) 1.80 \%$, sodium pyrophosphate $0.14 \%$, sodium tripolyphosphate $0.08 \%$, sodium hexametphosphate $0.08 \%$ and white pepper powder $0.30 \% . \mathrm{NaCl}$ and polyphosphates were analytical grade and were purchased from Xuzhou Tianjia Chemical Plant Co. Limited (Xuzhou, China). The white pepper powder was purchased from Kunshan Spices Co. Limited (Kunshan, China). The ratio of meat weight to marinade weight was 100:35 for all marination treatments. It had been observed in preliminary trials that when the vacuum continuous tumbling time was $8 \mathrm{~h}$, the best quality characteristics (much higher product yield, lower cooking loss and shear force value) of prepared pork chops were obtained, thus, this time was selected. The cut pork chops were placed in a vacuum tumbler (ESK-125, Kakona Gmbh Company, Kempten, Germany) together with marinade for tumbling marination treatments. While, for SM treatment, the 4 chop samples were placed into a tank together with marinade and left without any agitation. After marination, the samples were immediately patted with tissue paper to absorb surface water prior to further analysis together with the 4 fresh chop samples (CG). All the four treatments of the design were applied to a single pork loin so that the pork loin was considered a replicate. The whole design was replicated three times resulting in a total of 48 chop samples.

\section{pH measurement}

The $\mathrm{pH}$ measurement was performed using a HI9125 portable waterproof $\mathrm{pH}$ meter (HANNA instruments, ClujNapoca, Romania) immediately after respective treatments, following the method as described by Straadt et al. (2007). Using a scalpel, small incisions were made in the samples. A $\mathrm{pH}$ probe was inserted into the incision and the reading was recorded. The $\mathrm{pH}$ electrode was calibrated with $\mathrm{pH}$ 4.01 and 7.00 buffers before testing and compensated at temperature of $20^{\circ} \mathrm{C}$ together with the samples. Each chop sample was measured 3 times at various points and the average value was used.

\section{Instrumental color determination}

Instrumental color determination was made by the Commission Internationale de l'Eclairage L*a*b* system using a colorimeter (CR400, Konica Minolta Sensing, Inc., Osaka, Japan; calibrated with a white plate) on a fresh cut surface of the samples after blooming in daylight in air at a temperature of $20^{\circ} \mathrm{C}$ for approximately $20 \mathrm{~min}$. The aperture of color meter was placed on the surface of samples vertically and then $\mathrm{L}^{*}$ (lightness), $\mathrm{a}^{*}$ 
(redness/greenness), b* (yellowness/blueness) values were recorded. Each chop sample was measured 3 times at various points and the average value was used.

\section{Pressing loss}

The pressing loss was measured after respective treatments according to a filter paper press method of Farouk and Wieliczko (2003) with some modifications. Briefly, a sample of approximately $5 \mathrm{~g}$ was cut from each pork chop with a cylinder sampler $25.2 \mathrm{~mm}$ in diameter. Then the sample was wrapped with 16 layers of tissue papers and pressed under a force of $35 \mathrm{~kg}$ weight for $5 \mathrm{~min}$ using a compression machine (YYW-2, Nanjing Soil Instrument, Nanjing, China). The amount of expressed water was calculated as a ratio of the pressing loss (\%).

\section{Cooking loss}

Cooking loss was measured by the method of Sheard and Tali (2004) with some modifications. A sample of approximately $30 \mathrm{~g}$ was cut from each pork chop after treatments and the actual weight was recorded. After packaged and sealed in a boilable bag, sample was cooked to an internal temperature of $75^{\circ} \mathrm{C}$ in a water bath of $78^{\circ} \mathrm{C}$. The internal temperature was measured by inserting a digital temperature probe (Testo 735-2, Testo AG, Lenzkirch, Germany) into the packed pork chops. Upon completion of cooking, the meat sample was removed and cooled to room temperature of $20^{\circ} \mathrm{C}$, dabbed with tissue papers to absorb residual surface moisture and the weight was recorded again. The cooking loss (\%) was determined as the difference between the fresh and cooked weight divided by the fresh weight.

\section{Product yield}

The weight of fresh pork chops (before marination experiment) was recorded as $\mathrm{W}_{1}$. The weight of marinated and cooked pork chops was recorded as $\mathrm{W}_{2}$. The following formula was used to calculate the product yield as described by Cheng et al. (2011): Product yield $(\%)=\mathrm{W}_{2} / \mathrm{W}_{1} \times 100$.

\section{Shear force measurement}

Shear force measurement was performed according to the procedures of Baublits et al. (2005) with some modifications. After cooking, each pork chop sample was cut into 3 rectangular shaped strips $(1 \mathrm{~cm} \times 1 \mathrm{~cm} \times 3 \mathrm{~cm})$, parallel to the muscle fiber direction (4 pork chop samples per treatment). Then a strip sample was cut off perpendicular to the muscle fiber direction using a Digital Meat Tenderness Meter (C-LM3B, Northeast Agricultural University, Harbin, China). Maximum peak force recorded during the test was reported as shear force value and the result was expressed in Newton (N). Each rectangular shaped strip was measured 2 times and the average value was used.

\section{Texture profile analyses}

Texture profile analyses (TPA) was performed using a texture analyzer (TA-XT. plus, Stable Micro system Ltd., Surry, UK) at room temperature of $20^{\circ} \mathrm{C}$ as described by Bourne (1978) and Kim et al. (2012) with some modifications. After cooking and prior to analysis, the sample was allowed to equilibrate to room temperature of $20^{\circ} \mathrm{C}$ and then cut into $20 \mathrm{~mm}$ height across to the myofiber direction by a cylinder sampler of $25.2 \mathrm{~mm}$ in diameter. Then the cut sample was compressed applying a double compression test (TPA test) across the myofiber direction to $50 \%$ of their original height at $1.0 \mathrm{~mm} / \mathrm{s}$ using a cylindricalshaped piston $50 \mathrm{~mm}$ in diameter $(\mathrm{P} / 50)$. The conditions of texture analysis were as follows: pre-test speed $2.0 \mathrm{~mm} / \mathrm{s}$, post-test speed $5.0 \mathrm{~mm} / \mathrm{s}$, return distance $30 \mathrm{~mm}$, trigger force $10 \mathrm{~g}$. The calculation of TPA values was obtained by graphing a curve using force and time plots. The TPA attributes were calculated as described by Gurikar et al. (2014).

\section{Sensory evaluation}

Pork chops were assessed for a number of sensory characteristics by an experienced eight member trained panel in sensory evaluation using the protocol of the American Meat Science Association (1995). At first, necessary preliminary training sessions were conducted to familiarize the panelists with the characteristics to be evaluated (i.e. tenderness, color, juiciness, overall flavor and overall acceptability) by the method of Ruiz de Huidobro et al. (2003) with some modifications; this method used reference scales to assess intensity of characteristics parameters and proposed some foods as standards for intensity points. For the testing sessions, the characteristics were evaluated using a 1 to 6 point category scale $(6=$ excellent color uniformity/extremely good flavor/extremely acceptable; 1 = very poor color/very poor flavor/not acceptable) or 1 to 8 point category scale ( $8=$ extremely tender/juicy; $1=$ extremely tough/dry). Chop samples were prepared for presentation by cutting $2 \mathrm{~mm}$ thick slice (parallel to the muscle fiber direction) immediately after the cooking process. Every five slice samples in the tray were labeled with three digit random numbers and served in random order to each panelist in individual booths at room temperature of $20^{\circ} \mathrm{C}$. Each treatment was presented to each panelist twice for each of three replicates. Water was provided to rinse the mouth between the samples.

\section{Statistical analysis}

All data were analyzed by one-way analysis of variance using the general linear model (GLM) procedure of the SAS 
Table 1. Effect of different tumbling marination treatments on the product yield, $\mathrm{pH}$, meat colour, pressing loss, cooking loss and shear force value of prepared pork chops

\begin{tabular}{|c|c|c|c|c|}
\hline Items & $\mathrm{CG}$ & SM & CT & IT \\
\hline Product yield (\%) & $72.40 \pm 0.32^{\mathrm{d}}$ & $77.73 \pm 0.09^{c}$ & $81.88 \pm 0.34^{\mathrm{a}}$ & $79.55 \pm 0.09^{\mathrm{b}}$ \\
\hline $\mathrm{pH}$ & $5.50 \pm 0.07^{\mathrm{c}}$ & $5.52 \pm 0.02^{\mathrm{bc}}$ & $5.94 \pm 0.08^{\mathrm{a}}$ & $5.67 \pm 0.02^{\mathrm{b}}$ \\
\hline $\mathrm{L}^{*}$ & $41.73 \pm 0.27^{\mathrm{c}}$ & $45.94 \pm 0.31^{\mathrm{b}}$ & $45.59 \pm 0.49^{b}$ & $47.29 \pm 0.44^{\mathrm{a}}$ \\
\hline$a^{*}$ & $5.85 \pm 0.17^{\mathrm{c}}$ & $7.60 \pm 0.40^{\mathrm{b}}$ & $6.38 \pm 0.16^{\mathrm{c}}$ & $8.88 \pm 0.12^{\mathrm{a}}$ \\
\hline$b^{*}$ & $0.47 \pm 0.01^{\mathrm{c}}$ & $1.00 \pm 0.08^{\mathrm{b}}$ & $2.27 \pm 0.04^{\mathrm{a}}$ & $0.36 \pm 0.04^{\mathrm{c}}$ \\
\hline Pressing loss (\%) & $43.36 \pm 0.43^{\mathrm{a}}$ & $41.21 \pm 0.31^{\mathrm{b}}$ & $37.67 \pm 0.30^{c}$ & $38.84 \pm 0.48^{\mathrm{c}}$ \\
\hline Cooking loss (\%) & $27.33 \pm 0.57^{\mathrm{a}}$ & $23.78 \pm 0.36^{\mathrm{b}}$ & $14.14 \pm 0.53^{\mathrm{c}}$ & $22.73 \pm 0.14^{b}$ \\
\hline Shear force value $(\mathrm{N})$ & $27.75 \pm 0.21^{\mathrm{a}}$ & $21.07 \pm 0.42^{\mathrm{b}}$ & $12.41 \pm 0.56^{\mathrm{d}}$ & $14.93 \pm 0.24^{\mathrm{c}}$ \\
\hline
\end{tabular}

CG, control group; SM, conventional static marination; CT, vacuum continuous tumbling marination; IT, vacuum intermittent tumbling marination.

a,b,c,d Means within the same row with no common superscript differ significantly $(\mathrm{p}<0.05)$. Values are reported as means \pm standard error of three replicates.

statistical package (SAS 8.1, SAS Inc., Chicago, MI, USA). The Duncan's New Multiple Range Test was used to detect significant differences between individual means when the treatment effect was significant $(\mathrm{p}<0.05)$. All values were $\mathrm{s}$ reported as means \pm standard error for each treatment of three replicates.

\section{RESULTS}

\section{Product yield}

It can be seen in Table 1 that all marination treatments increased $(\mathrm{p}<0.05)$ product yield $(\%)$ of prepared pork chops compared with CG treatment. The CT and IT treatments increased $(\mathrm{p}<0.05)$ product yield of prepared pork chops more than SM treatment, and CT treatment increased $(\mathrm{p}<0.05)$ the product yield more than IT treatment.

\section{pH value}

As shown in Table 1, $\mathrm{pH}$ values of CT and IT treatments were higher $(\mathrm{p}<0.05)$ than $\mathrm{CG}$ treatment, and $\mathrm{pH}$ of $\mathrm{CT}$ treatment was higher $(\mathrm{p}<0.05)$ compared with IT treatment. However, there was no difference in $\mathrm{pH}$ between SM and IT treatments.

\section{Color determination}

Color analysis results are shown in Table 1. All marination treatments increased $(p<0.05) \mathrm{L}^{*}$ value of pork chops in comparison to the control. The IT treatment increased $(\mathrm{p}<0.05) \mathrm{L}^{*}$ and $\mathrm{a}^{*}$ values more than the other treatments, however, no significant difference in the $\mathrm{L}^{*}$ value between SM and CT treatments was observed. The SM and CT treatments increased $(\mathrm{p}<0.05) b^{*}$ value above the other treatments, CT treatment also increased $(p<0.05)$ $b^{*}$ value compared with SM treatment.

\section{Pressing loss, cooking loss and shear force value}

Table 1 shows the effect of different tumbling marination treatments on the pressing loss (\%), cooking loss $(\%)$ and shear force value $(\mathrm{N})$ of prepared pork chops. It is obvious that all marination treatments decreased $(\mathrm{p}<0.05)$ the pressing loss, cooking loss and shear force value of pork chops in comparison to the control. The CT and IT treatments decreased $(\mathrm{p}<0.05)$ pressing loss and shear force value more than did the SM treatment. The CT treatment decreased $(p<0.05)$ shear force value compared with IT treatment. There was no pronounced effect in pressing loss between CT and IT treatments, but the best result was also achieved by applying CT treatment.

\section{Texture profile analyses}

The TPA results are showed in Table 2. In the present study, all marination treatments decreased $(p<0.05)$ hardness, cohesiveness and gumminess of prepared pork chops in comparison to the control. The CT and IT treatments decreased $(\mathrm{p}<0.05)$ hardness, cohesiveness and gumminess compared with SM treatment. The CT treatment

Table 2. Effect of different tumbling marination treatments on the textural characteristics of prepared pork chops

\begin{tabular}{lrrrr}
\hline Items & \multicolumn{1}{c}{ CG } & SM & CT & IT \\
\hline Hardness (g) & $14,154.8 \pm 159.7^{\mathrm{a}}$ & $13,484.5 \pm 67.5^{\mathrm{b}}$ & $8,602.5 \pm 26.8^{\mathrm{d}}$ & $10,742.9 \pm 53.5^{\mathrm{c}}$ \\
Springiness (cm) & $0.57 \pm 0.005^{\mathrm{b}}$ & $0.63 \pm 0.003^{\mathrm{a}}$ & $0.64 \pm 0.007^{\mathrm{a}}$ & $0.62 \pm 0.003^{\mathrm{a}}$ \\
Cohesiveness (-) & $0.68 \pm 0.001^{\mathrm{a}}$ & $0.65 \pm 0.005^{\mathrm{b}}$ & $0.64 \pm 0.002^{\mathrm{c}}$ & $0.62 \pm 0.007^{\mathrm{d}}$ \\
Gumminess (g) & $9,636.2 \pm 64.8^{\mathrm{a}}$ & $8,832.4 \pm 43.1^{\mathrm{b}}$ & $5,487.3 \pm 14.3^{\mathrm{d}}$ & $6,752.0 \pm 36.9^{\mathrm{c}}$ \\
Chewiness (g×cm) & $5,554.7 \pm 88.5^{\mathrm{a}}$ & $5,676.8 \pm 30.1^{\mathrm{a}}$ & $3,505.9 \pm 49.6^{\mathrm{c}}$ & $4,185.3 \pm 72.1^{\mathrm{b}}$ \\
\hline
\end{tabular}

CG, control group; SM, conventional static marination; CT, vacuum continuous tumbling marination; IT, vacuum intermittent tumbling marination. a,b,c,d Means within the same row with no common superscript differ significantly $(\mathrm{p}<0.05)$. Values are reported as means \pm standard error of three replicates. 
decreased $(\mathrm{p}<0.05)$ hardness and gumminess compared with IT treatment. However, IT treatment decreased $(\mathrm{p}<0.05)$ cohesiveness compared with CT treatment. The CT and IT treatments decreased $(\mathrm{p}<0.05)$ chewiness compared with other treatments, and CT treatment decreased $(\mathrm{p}<0.05)$ chewiness than IT treatment. Meanwhile, all marination treatments increased $(\mathrm{p}<0.05)$ springiness of prepared pork chops when compared to CG treatment. Although there was no significant difference in springiness among SM, CT, and IT treatments, the springiness of CT treatment had the numerically highest value. These results indicated that the TPA characteristics (except for cohesiveness) of prepared pork chops assigned to CT treatment were the best.

\section{Sensory evaluation}

It is seen in Table 3 that all marination treatments increased $(\mathrm{p}<0.05)$ tenderness, color, juiciness, overall flavor and overall acceptability of prepared pork chops compared with the control. The CT and IT treatments increased $(p<0.05)$ tenderness, juiciness and overall acceptability compared with other treatments. The CT treatment increased $(\mathrm{p}<0.05)$ the tenderness, juiciness and overall acceptability compared with IT treatment. There was no significant difference in sensory color among all marination treatments, but the best color result was also achieved by applying CT treatment. The overall flavor of CT treatment was higher $(\mathrm{p}<0.05)$ than $\mathrm{SM}$ and IT treatments, but there was no significant difference in overall flavor between SM and IT treatments. These results indicated that the sensory evaluation of prepared pork chops subjected to CT treatment was the best.

\section{DISCUSSION}

The $\mathrm{pH}$ value is one of the most important indicators of meat quality. Results from Table 1 demonstrated the marinade containing salt and phosphate increased $\mathrm{pH}$ value, which was similar with Offer and Trinick (1983) and Cheng and Sun (2008), who explained that chloride ions formed an ion"cloud"around the meat protein filaments, which resulted an increase of net negative charges and osmotic pressure within the myofibrils, further caused the swelling of filament lattice and the increasing of the $\mathrm{pH}$ value. Meanwhile, alkalescent polyphosphate also had the function to increase the $\mathrm{pH}$ value (Baublits et al., 2005). Besides, Ockerman and Organisciak (1978) reported that mechanical tumbling involving meat rotating, falling and contacting with metal walls and paddles in a tumbler drum could increase the migration of the marinade in tumbled meats which accelerating marinated effects. Tumbling could also increase the activity of various proteolytic enzymes, which facilitated the protein degradation and the meat maturity, thus increasing the $\mathrm{pH}$ (Lawrie and Ledward, 2006). In addition, the CT treatment achieved the highest $\mathrm{pH}$, which indicated that continuous mechanical tumbling was the most effective.

Basically, the water holding capacity (WHC) is a term used to describe the ability of muscle to bind and hold water under a variety of conditions and always related to meat behaviors during cooking such as texture, juiciness, flavor and the economic product yield (Lawrie and Ledward, 2006; Siró et al., 2009). In this study, the WHC was expressed as pressing loss and cooking loss (Table 1). Product yield is an important parameter in meat industry in relation to the intuitive economic benefits (Cheng and Sun, 2008). Based on the results of Table 1, one can conclude that the tumbling and marination significantly improved the WHC of pork chops. The present results confirmed the findings of Vote et al. (2000), who explained that the swelling of myofibrillar filaments and the increasing of $\mathrm{pH}$ as well as the extraction of SSP (including myosin, actin, actomyosin, and tropomyosin, etc.) aided in reducing pressing loss and cooking loss. As for SSP, after heated, sol state SSP forms a gel network within a densely spatial grid structure, which facilitates wrapping more water and fat, or adsorbing more moisture by physical capillary force, therefore reducing the cooking loss and improving product yield (Xiong and Kupski, 1999; Pietrasik and Shand, 2004). Besides, tumbling could facilitate the above effects of marination through the structural destruction of muscle

Table 3. Effect of different tumbling marination treatments on the sensory attributes of prepared pork chops

\begin{tabular}{lcccc}
\hline Items & CG & SM & CT & IT \\
\hline Tenderness & $2.67 \pm 0.13^{\mathrm{d}}$ & $4.40 \pm 0.20^{\mathrm{c}}$ & $7.13 \pm 0.17^{\mathrm{a}}$ & $5.60 \pm 0.23^{\mathrm{b}}$ \\
Color & $2.38 \pm 0.29^{\mathrm{b}}$ & $3.40 \pm 0.15^{\mathrm{a}}$ & $4.00 \pm 0.13^{\mathrm{a}}$ & $3.80 \pm 0.13^{\mathrm{a}}$ \\
O/F & $1.95 \pm 0.19^{\mathrm{c}}$ & $3.75 \pm 0.25^{\mathrm{b}}$ & $5.35 \pm 0.18^{\mathrm{a}}$ & $4.07 \pm 0.46^{\mathrm{b}}$ \\
Juiciness & $2.40 \pm 0.20^{\mathrm{d}}$ & $4.40 \pm 0.23^{\mathrm{c}}$ & $7.13 \pm 0.13^{\mathrm{a}}$ & $5.40 \pm 0.31^{\mathrm{b}}$ \\
O/A & $2.00 \pm 0.10^{\mathrm{d}}$ & $3.35 \pm 0.18^{\mathrm{c}}$ & $5.40 \pm 0.09^{\mathrm{a}}$ & $4.22 \pm 0.36^{\mathrm{b}}$ \\
\hline
\end{tabular}

CG, control group; SM, conventional static marination; CT, vacuum continuous tumbling marination; IT, vacuum intermittent tumbling marination; O/F, overall flavor; O/A, overall acceptability.

Tenderness and juiciness were evaluated by means of 8 -point scales ( $8=$ extremely tender/juicy; $1=$ extremely tough/dry). Color, overall flavor, overall acceptability were evaluated by means of 6 -point scales $(6=$ excellent color uniformity/extremely good flavor/extremely acceptable; $1=$ very poor color/very poor flavor/not acceptable).

${ }_{a, b, c, d}$ Means within the same row with no common superscript differ significantly $(\mathrm{p}<0.05)$. Values are reported as means \pm standard error of three replicates. 
fibers and consequently improving the WHC and product yield (Cassidy et al., 1978; Tyszkiewicz et al., 1997), moreover, results showed continuous mechanical tumbling was more effective.

In general, tenderness is one of the most important eating quality attributes affecting consumer satisfaction and palatability characteristics of meats. The major components related with muscle tenderness were the myofibrillar proteins, connective tissue protein and collagen. Table 1 shows that $\mathrm{s}$ the $\mathrm{CT}$ treatment reduced shear force value nearby up to a half, which was in accordance with previous observations obtained by Cassidy et al. (1978), Tyszkiewicz et al. (1997) and Hayes et al. (2006), who indicated that the shear force value was closely related to the WHC; after cooking process, amounts of water and fat within the SSP gel grid structure could lubricate muscle fibers when chewing them; and tumbling was more important in loosening the structure of muscle fibers, destroying the connections between the myofibrils and collagen of connective tissue, and finally decreasing the shear force value and increasing the tenderness of pork chops. Furthermore, Zapata (1981) also reported that vacuum tumbling resulted in higher meat tenderness than novacuum tumbling.

Meat color was the most significant after texture in a comparison of the attributes of meat quality (Rødbotten et al., 2004). Meat color was mainly determined by the chemical state of the myoglobin molecules. In the present study, the combination of marination and tumbling increased $\mathrm{L}^{*}$ value and IT treatment achieved the highest value, which might be ascribed to the increasing of moisture and SSP of muscle surface with the longest immersing time of IT treatment, and this resulted in a higher light reflection, a lighter surface color of pork chops (Lawrie and Ledward, 2006; Yusop et al., 2012). For the increasing of a* value in CT and IT treatments, it was primarily because the transformation of bright red oxymyoglobin or light brown metmyoglobin to purplish-red myoglobin was accelerated by the denaturation of the globins or the low oxygen tension during the vacuum marination process (Deman 1999; Lawrie and Ledward 2006), hence the meat color would present darker and redder. However, the increasing of $\mathrm{a}^{*}$ value in SM treatment was probably due to the extending of exposure time of meat and air, which increased the content of brown metmyoglobin. Yusop et al. (2012) also reported that tumbling treatment significantly increased $a^{*}$ and $b^{*}$ values of chicken breast fillets compared with injection and immersion treatments, and they explained that this might be ascribed to the denaturation of meat proteins causing by tumbling process. However, further studies should be conducted to elucidate the result that $\mathrm{CT}$ treatment significantly increased $b^{*}$ value compared with other treatments.

Texture and tenderness are presently most important of all the attributes of meat eating quality by consumers (Lawrie and Ledward, 2006). The association of marination and tumbling likely assisted in reducing hardness, chewiness, cohesiveness and gumminess, this could be explained by the changes of shear force as they were highly related (Lachowicz et al., 2003; Pietrasik and Shand, 2004; Siró et al., 2009). Whereas the improving of springiness was probably due to the SSP forming elastic gel network (densely spatial grid structure wrapping amounts of water and fat) and the disruption of myofibrils and collagen (Mueller, 1991; Pietrasik and Shand, 2004; Gurikar et al., 2014). And finally, the best results of TPA properties (except for cohesiveness) were achieved by applying CT treatment, which also indicated vacuum continuous tumbling was more effective.

Sensory evaluation is a subjective method of determining the quality of meat products by the use of final comprehensive scores. The mechanism responsible for the increased tenderness and juiciness was connected with the destroyed connection between the myofibrils and collagen as well as the higher WHC, as described by Dzudie and Okubanjo (1999), Lachowicz et al. (2003) and Baublits et al. (2005). The complicated chemical reactions and the degradation of protein polypeptide chains causing by marinade permeating into pork chops might contribute to the development of overall flavor (Vestergaard et al., 2005). Similarly, Dzudie and Okubanjo (1999) and Hayes et al. (2007) reported tumbling marinated samples had higher color score and flavor acceptability compared to the other treatments, they explained that the marination and tumbling resulted in improving the consistency of color distribution throughout the meat and also enhancing aroma and flavor acceptability. And finally, all these above functions significantly improved the sensory attributes of prepared pork chops, in particular by applying the vacuum continuous tumbling treatment.

\section{CONCLUSION}

For the prepared boneless pork chops, results from this study showed that both the CT treatment and the IT treatment effectively improved the quality characteristics of pork chops compared with SM treatment and the CG treatment. In addition, CT treatment was more effective in increasing the $\mathrm{pH}$, WHC, product yield, and further improving the physical characteristics and sensory qualities of pork chops compared with IT treatment. Given this, CT treatment should be chosen as the optimal treatment method for the processing production of this type of prepared boneless pork chops. 


\section{ACKNOWLEDGMENTS}

This study was funded by the National Science and Technology Pillar Program during the Twelfth Five-year Plan Period of China (2012BAD28B03), Three Agricultural Projects of Jiangsu Province of China (SX[2011]146), and the Fundamental Research Funds for the Central Universities of China (KYZ201222). We are grateful to Dr Ron Tume (CSIRO, Australia) for language improvement of the revised manuscript.

\section{REFERENCES}

Alvarado, C. and S. McKee. 2007. Marination to improve functional properties and safety of poultry meat. J. Appl. Poult. Res. 16:113-120.

Baublits, R. T., F. W. Pohlman, A. H. Brown Jr, and Z. B. Johnson. 2005. Effects of sodium chloride, phosphate type and concentration, and pump rate on beef biceps femoris quality and sensory characteristics. Meat Sci. 70:205-214.

Bourne, M. C. 1978. Texture Profile Analysis. Food Technol. 32:62-66, 73 .

Cassidy, R. O., H. W. Ockerman, B. Krol, P. S. Van Roon, R. F. Plimpton, and V. R. Cahill. 1978. Effect of tumbling method, phosphate level and final cook temperature on histological characteristics of tumbled porcine muscle tissue. J. Food Sci. 43:1514-1518.

Cheng, J. H., S. T. Wang, Y. M. Sun, and H. W. Ockerman. 2011. Effect of phosphate, ascorbic acid and $\alpha$-tocopherol injected at one-location with tumbling on quality of roast beef. Meat Sci. 87:223-228.

Cheng, Q. and D. W. Sun. 2008. Factors affecting the water holding capacity of red meat products: A review of recent research advances. Crit. Rev. Food Sci. 48:137-159.

deMan, J. M. 1999. Principles of Food Chemistry. 3rd edn. Springer, NY, USA.

Dzudie, T. and A. Okubanjo. 1999. Effects of rigor state and tumbling time on quality of goat hams. J. Food Eng. 42:103107.

Farouk, M. M. and K. J. Wieliczko. 2003. Effect of diet and fat content on the functional properties of thawed beef. Meat Sci. 64:451-458.

Gillett, T. A., R. D. Cassidy, and S. Simon. 1982. Ham massaging. Effect of massaging cycle, environmental temperature and pump level on yield, bind, and color of intermittently massaged hams. J. Food Sci. 47:1083-1088.

Gurikar, A. M., V. Lakshmanan, Y. P. Gadekar, B. D. Sharma, and A. S. R. Anjaneyulu. 2014. Effect of meat chunk size, massaging time and cooking time on quality of restructured pork blocks. J. Food Sci. Technol. 51:1363-1369.

Hayes, J. E., E. M. Desmond, D. J. Troy, D. J. Buckley, and R. Mehra. 2006. The effect of enhancement with salt, phosphate and milk proteins on the physical and sensory properties of pork loin. Meat Sci. 72:380-386.

Hayes, J. E., T. A. Kenny, P. Ward, and J. P. Kerry. 2007. Development of a modified dry curing process for beef. Meat Sci. 77:314-323.
Kim, S. Y., J. H. Choi, Y. S. Choi, H. Y. Kim, K. I. Ahn, H. W. Kim, T. H. Kim, D. H. Song, and C. J. Kim. 2012. Effects of low-temperature tumbling on the quality characteristics of restructured chicken breast ham. Korean J. Food Sci. Anim. Resour. 32:268-273.

Lachowicz, K., M. Sobczak, L. Gajowiecki, and A. Zych. 2003. Effects of massaging time on texture, rheological properties, and structure of three pork ham muscles. Meat Sci. 63:225-233.

Lawrie, R. A. and D. A. Ledward. 2006. Lawrie's Meat Science. 7th ed. Woodhead Publishing, Cambridge, England.

Mueller, W. D. 1991. Cooked cured products. Influence of manufacturing technology. Fleischwirtschaft 71:544-550.

Ockerman, H. W. and C. S. Organisciak. 1978. Diffusion of curing brine in tumbled and non-tumbled porcine tissue. J. Food Prot. 41:178-181.

Offer, G. and J. Trinick. 1983. On the mechanism of water holding in meat: The swelling and shrinking of myofibrils. Meat Sci. 8:245-281.

Pietrasik, Z. and P. J. Shand. 2003. The effect of quantity and timing of brine addition on water binding and textural characteristics of cooked beef rolls. Meat Sci. 65:771-778.

Pietrasik, Z. and P. J. Shand. 2004. Effect of blade tenderization and tumbling time on the processing characteristics and tenderness of injected cooked roast beef. Meat Sci. 66:871-879.

Plimpton, R. F., C. J. Perkins, T. L. Sefton, V. R. Cahill, and H. W. Ockerman. 1991. Rigor condition, tumbling and salt level influence on physical, chemical and quality characteristics of cured, boneless hams. J. Food Sci. 56:1514-1518.

Ruiz De Huidobro, F., E. Miguel, E. Onega, and B. Blázquez. 2003. Changes in meat quality characteristics of bovine meat during the first 6 days post mortem. Meat Sci. 65:1439-1446.

Rødbotten, M., E. Kubberød, P. Lea, and Ø. Ueland. 2004. A sensory map of the meat universe. Sensory profile of meat from 15 species. Meat Sci. 68:137-144.

SAS. 2006. SAS User's Guide: Statistics (Version 8.1 Ed.). SAS Inst. Inc., Cary, NC, USA.

Sheard, P. and A. Tali. 2004. Injection of salt, tripolyphosphate and bicarbonate marinade solutions to improve the yield and tenderness of cooked pork loin. Meat Sci. 68:305-311.

Siró, I., C. Ven, C. Balla, G. Jónás, I. Zeke, and L. Friedrich. 2009. Application of an ultrasonic assisted curing technique for improving the diffusion of sodium chloride in porcine meat. J. Food Eng. 91:353-362.

Straadt, I. K., M. Rasmussen, H. J. Andersen, and H. C. Bertram. 2007. Aging-induced changes in microstructure and water distribution in fresh and cooked pork in relation to waterholding capacity and cooking loss - A combined confocal laser scanning microscopy (CLSM) and low-field nuclear magnetic resonance relaxation study. Meat Sci.75:687-695.

Tyszkiewicz, I., B. M. Kłossowska, U. Wieczorek, and A. Jakubiec-Puka. 1997. Mechanical tenderisation of pork meat: Protein and water release due to tissue damage. J. Sci. Food Agric. 73:179-185.

Vestergaard, C., J. Risum, and J. Adler-Nissen. 2005. ${ }^{23} \mathrm{Na}-\mathrm{MRI}$ quantification of sodium and water mobility in pork during brine curing. Meat Sci. 69:663-672.

Vote, D., W. Platter, J. Tatum, G. Schmidt, K. Belk, G. Smith, and N. Speer. 2000. Injection of beef strip loins with solutions containing sodium tripolyphosphate, sodium lactate, and 
sodium chloride to enhance palatability. J. Anim. Sci. 78:952- Yusop, S. M., M. G. O'Sullivan, J. F. Kerry, and J. P. Kerry. 2012. 957.

Xiong, Y. L. and D. R. Kupski. 1999. Monitoring phosphate marinade penetration in tumbled chicken filets using a thinslicing, dye-tracing method. Poult. Sci. 78:1048-1052. Influence of processing method and holding time on the physical and sensory qualities of cooked marinated chicken breast fillets. LWT-Food Sci. Technol. 46:363-370. 